\title{
Management of biliary ascariasis: report of 21 cases
}

\author{
L.A. Lesmana
}

\begin{abstract}
Abstrak
Studi ini dilakukan untuk menilai penatalaksanaan askariasis bilier khususnya terapi endoskopik. Dari I Januari, 1986 sampai dengan 31 Desember 1996, pada pemeriksaan endoscopic retrograde cholangio-pancreatography (ERCP) ditemukan sebanyak 21 kasus askariasis bilier. Tiga dari 21 pasien telah menjalani sfingterotomi sebelumnya untuk pengeluaran batu saluran empedu (BSE) dan 4 pasien juga mempunyai BSE pada ERCP. Tiga belas dari 21 penderita (62\%) mengeluh kolik bilier berulang sedangkan 8 lainnya (38\%) mengalami kolangitis akut. UItrasound (US) dengan real time scanner mendeteksi cacing di dalam SE pada 7 dan 13 (54\%) penderita yang diperiksa. Tujuh belas pasien (81\%) menjalani sfingterotomi kecil diikuti dengan ekstraksi cacing dengan dormia basket. Pengeluaran cacing askaris berhasil pada $11(65 \%)$ dari 17 penderita sedangkan pada 6 lainnya dipasang kateter naso-bilier. Pembersihan saluran empedu didapatkan pada keenam penderita ini pada kolangiografi melalui kateter. Empat pasien sisanya (19\%) yang disertai BSE menjalani operasi tanpa penyulit. Sebagai kesimpulan, US dan ERCP sangat bermanfaat dalam diagnosis askariasis bilier dan terapi endoskopik perlu dipertimbangkan sebagai pilihan pertama pada pasien dengan obstruksi bilier simptomatik dan kolangitis akut.
\end{abstract}

\begin{abstract}
This study was carried out to assess the management of biliary ascariasis with special reference to endoscopic treatment. From January 1, 1986 to December 31, 1996, twenty one cases of biliary ascariasis were detected at endoscopic retrograde cholangiopancreatography (ERCP) examination. Thirteen of 21 patients $(62 \%)$ presented with recurrent biliary colic and the remaining 8 patients (38\%) developed acute cholangitis. Ultrasound (US) using a real time scanner detected the worm in the CBD in 7 of $13(54 \%)$ patients examined. Three of 21 patients had prior sphincterotomy for removal of common ble duct (CBD) stones and 4 patients had concurrent CBD stones at ERCP. Seventeen patients (81\%) underwent a small sphincterotomy followed by extraction of worm with a dormia basket. Removal of worm was successful in $11(65 \%)$ of these patients, whereas in the other 6 patients a naso-biliary tube was inserted for the administration of pyrantel pamoate directly into the bile duct. Interval duct clearance was obtained in all these 6 patients at subsequent tube cholangiography. The remaining 4 patients (19\%) with CBD stones underwent uneventful surgery. In conclusion, US and ERCP are very useful in the diagnosis of biliary ascariasis and endoscopic treatment should be considered as the first treatment of choice for those patients with symptomatic biliary obstruction and acute cholangitis.
\end{abstract}

Keywords : Biliary ascariasis, ultrasound, endoscopic retrograde cholangio-pancreatography

\section{INTRODUCTION}

Ascariasis is one of the most frequent helminthic diseases in humans. ${ }^{1}$ It occurs mainly in countries where the standard of public health and personal hygiene are low. The adult worm of ascaris commonly lives in the intestinal lumen without any significant symptoms. ${ }^{2}$ However, when aggregated into worms masses they may cause intestinal obstruction, volvulus, and perforation of the bowel. Ascaris may also invade into the biliary tree which can cause recurrent biliary colic, acute cholangitis, cholecystitis, and pancreatitis. ${ }^{2-4}$

Department of Medicine, University of Indonesia/Dr. Cipto Mangunkusumo Hospital, Jakarta, Indonesia
After invasion into the bile duct, the worms usually migrate into the duodenum within a period of two weeks. Endoscopic retrograde cholangiography is an excellent, diagnostic modality to delineate worms in the biliary tree. ${ }^{2,5-7}$ Some investigators have also described the sonographic features of ascaris in the bile duct. $5,7-9$

The majority of patients with biliary ascariasis can be managed conservatively with simptomatic treatment and antihelminthic drugs. ${ }^{2,10}$ Endoscopic treatment of biliary ascariasis has also been reported. $6,11,12$

The purpose of this study was to report our experience in the management of biliary ascariasis with special reference to endoscopic treatment. 


\section{PATIENTS AND METHODS}

From January 1, 1986 to December 31, 1996, 2046 endoscopic retrograde cholangio-pancreatography (ERCP) examinations were performed for biliopancreatic disorders. ${ }^{5}$ ERCP was performed using standard technique under intravenous sedation with Olympus duodenoscopes type JB3, JB4, JF IT-10 or JF IT-20. Twenty one cases with biliary ascariasis were detected as smooth, long, linear filling defects in the bile duct (figure1). All these patients presented with recurrent biliary colic and acute cholangitis.

Routine hemogram, liver function tests, and serum amylase determinations were carried out according to standard methods. ${ }^{2}$
Thirteen of 21 patients had undergone ultrasound (US) ${ }^{3}$ examination prior to ERCP in several other hospitals using a real time scanner. Sonographic features of worm in the biliary tree were defined as long, linear, parallel echogenic strips without shadowing (figure 2).

All patients were initially treated with intravenous fluids and analgesic. Those with acute cholangitis also received antibiotics.

In 17 patients with biliary ascariasis without common bile duct stones a small sphincterotomy was carried out to facilitate insertion of dormia baskets for worm extraction.

The remaining four patients which were associated with rather big common bile duct (CBD) stones underwent surgery.

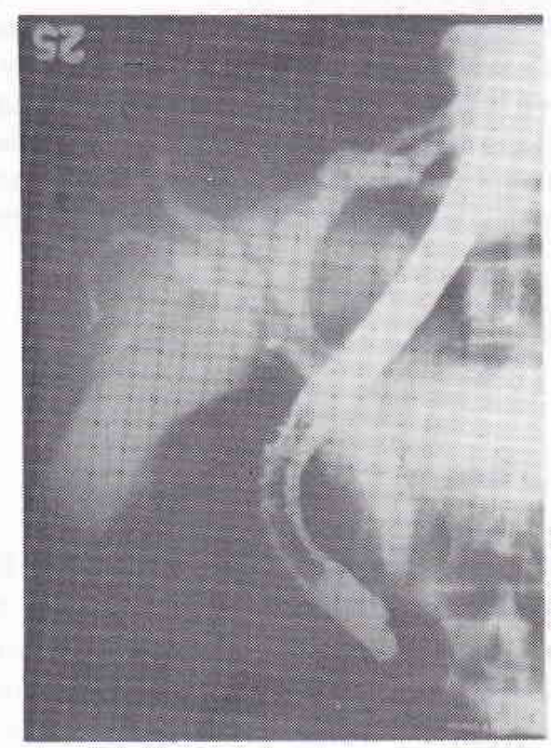

Figure 1. Ascaris in the bile duct detected as a linear filling defect at ERCP

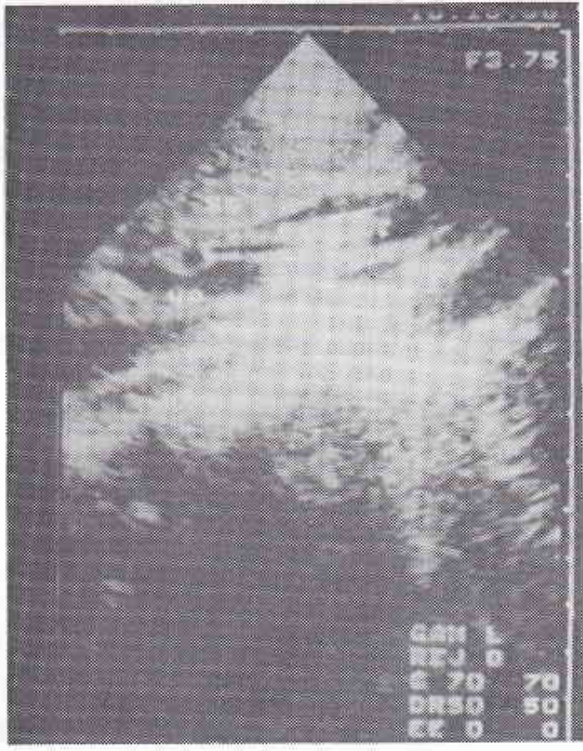

Figure 2. Charactersitic of sonographic features of worm in the biliary-tree are linear, parallel, echogenic strips $(T)$ without shadowing 
All patients received anthelminthic (pyrantel pamoate) therapy in single dose of $10 \mathrm{mg} / \mathrm{kg}$ body weight.

\section{RESULTS}

Of the 21 patients proven biliary ascariasis with ERCP there were 13 females and 8 males with an average age of 45 years (range $26-55$ years).

Biliary ascariasis was detected with US in seven of 13 patients examined (54\%) and biliary dilatation was reported in the remaining 6 patients. In all patients no part of the worm was protruding from the papilla. Thirteen $(62 \%)$ patients presented recurrent biliary colic and the remaining $8(38 \%)$ patients developed

Table 1. Clinical presentation of 21 patients with biliary ascariasis

\begin{tabular}{lrl}
\hline & $\mathrm{N}$ & $\%$ \\
\hline Recurrent biliary colic & 13 & 62 \\
Acute cholangitis & 8 & 38 \\
\hline Total & 21 & 100 \\
\hline
\end{tabular}

acute cholangitis (table 1). Laboratory findings in all patients were comparable with biliary obstruction?

Endoscopic treatment was performed in 17 patients $(81 \%)$; extraction of the worm from the bile duct was successful in 11 patients (65\%) (figure 3 and figure 4 ). In six patients with worm-extraction failure a nasobiliary tube was then inserted and pyrantel pamoate $(10 \mathrm{cc})$ was instilled directly into the biliary tract via the tube. Three days later duct clearance was obtained in all these 6 patients at tube cholangiography.

Three of the 21 patients had prior sphincterotomy for removal of CBD stones and four patients had concurrent relative big CBD stones at ERCP (figure 5). Those four patients associated with CBD stones underwent uneventful surgery (figure 6).

\section{DISCUSSION}

The present study supports previous reports that in endemic area biliary ascariasis should be included into differential diagnosis in patients with biliary colic and acute cholangitis. ${ }^{2,8}$ Our data also show that even patients who have undergone sphincterotomy can develop biliary ascariasis which is in agreement with a former case report. ${ }^{13}$

US examination could only achieve sensitivity rate of $54 \%$ for detecting worm in the biliary-tract which is lower compared to the previous series. ${ }^{5,7-9}$ This discrepancy may partly be explained by the variation in experience of the sonologists since the procedures were performed in several hospitals. A recent study shown that sensitivity of US could reach $100 \%$ without any false positive diagnosis in 19 surgically proven biliary ascariasis cases. ${ }^{9}$ The most prevalent sonographic findings were linear, echogenic nonshadowing tubes in 15 patients (79\%) and varying degree of biliary dilatation in $9(47 \%)$.

ERCP has been proved to be the most reliable modality in the detection of ascaris in the biliary-system. However, this delicate endoscopic technique is not available in most medical centres in Indonesia. Therefore,

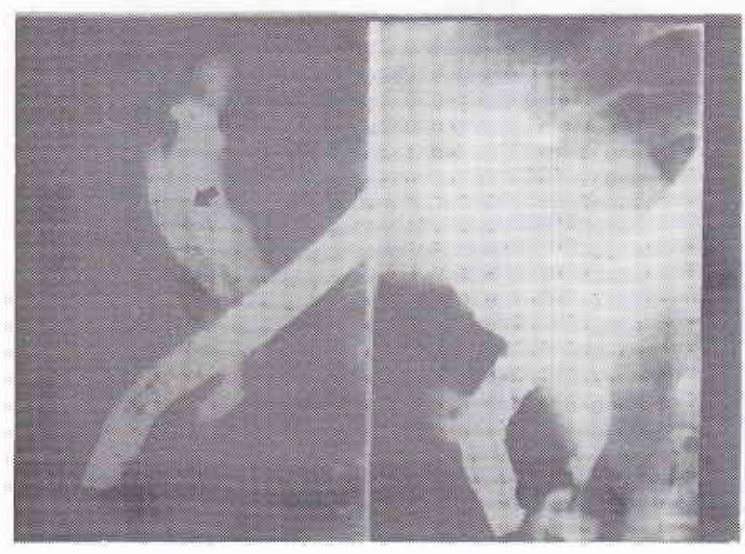

Figure 3. ERCP shows a worm in the common bile duct (arrow, left) and duct clearance after extraction of the worm (right) 
US as a rapid, non-invasive examination should be the primary of choice in diagnosing biliary ascariasis. ${ }^{9}$

Endoscopic extraction of ascaris from the common bile duct is relatively easy if some part of the worm is protruding from the papilla. ${ }^{12,13}$ Our success rate of endoscopic treatment of the worm of $65 \%$ is lower compared to the previous report using a balloon catheter or a dormia basket. ${ }^{6}$ In our experience, there was no special trick to catch the worm ${ }^{10}$ with a dormia basket so that the successful removal might be related to the position and location of the ascaris in the bile duct. The use of occlusion balloon catheter might be an alternative method to extract the worms. ${ }^{6}$ The advantage of endoscopic treatment was the rapid relief of biliary symptoms in all patients.
In six patients receiving a nasobiliary tube anthelminthic was also administered into the common bile duct via the tube hoping the direct effect of drug on the worm as previously reported. ${ }^{10}$

However, this approach is not generally accepted since a dead worm often fails to move out the biliary tract into the duodenum and furthermore pyrantel pamoate has no enterohepatic circulation. ${ }^{14}$

Therefore, the disappearance of ascaris in all these 6 patients obtained at subsequent tube cholangiography was probably due to the spontaneous moving of the worm into the duodenum via a relative big orifice of the papilla after sphincterotomy. The insertion of a nasobiliary tube might be useful to monitor duct

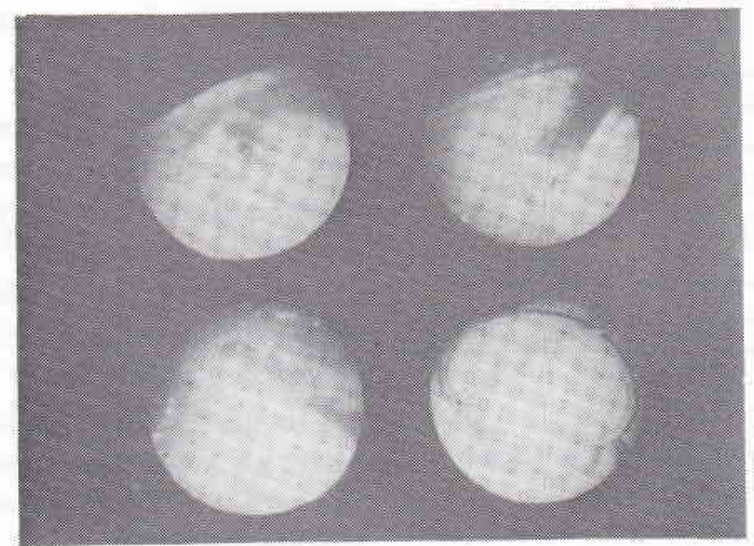

Figure 4. Endoscopic findings show: papilla of Vater after small sphincterotomy (upper left), a worm is extracted out of the papilla with a dormia basket (upper right and lower left), the live worm after removal from the duodenoscope

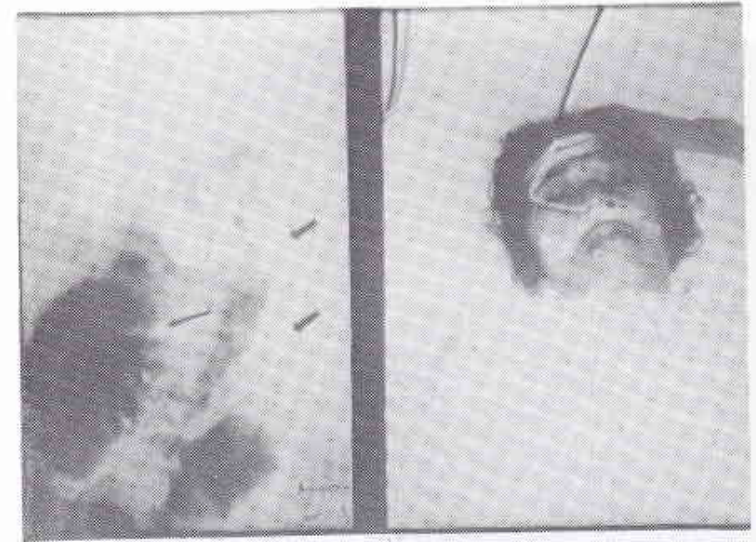

Figure 5. A worm in the common bile duct at ERCP after extraction failure (left) and a naso-biliary iube is inserted for administration of anthelmintic (right) 


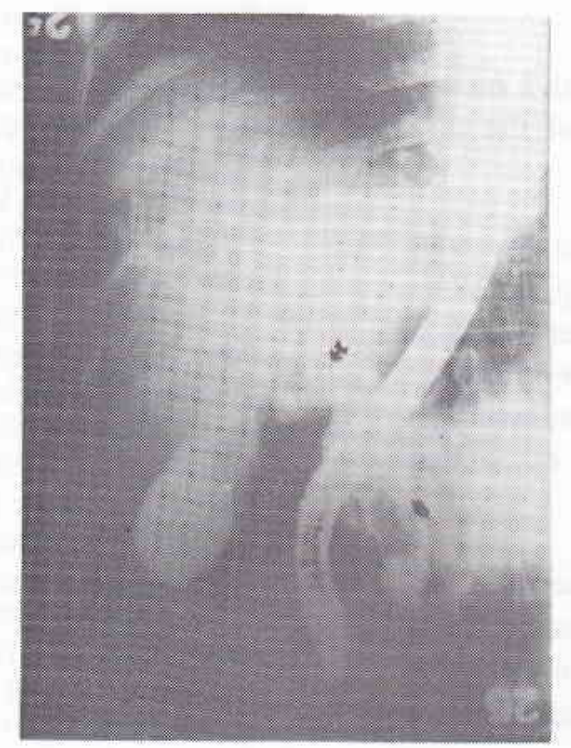

Figure 6. ERCP reveals a worm (upper arrow) associated with a relative big stone (lower arrow) in the common bile duct

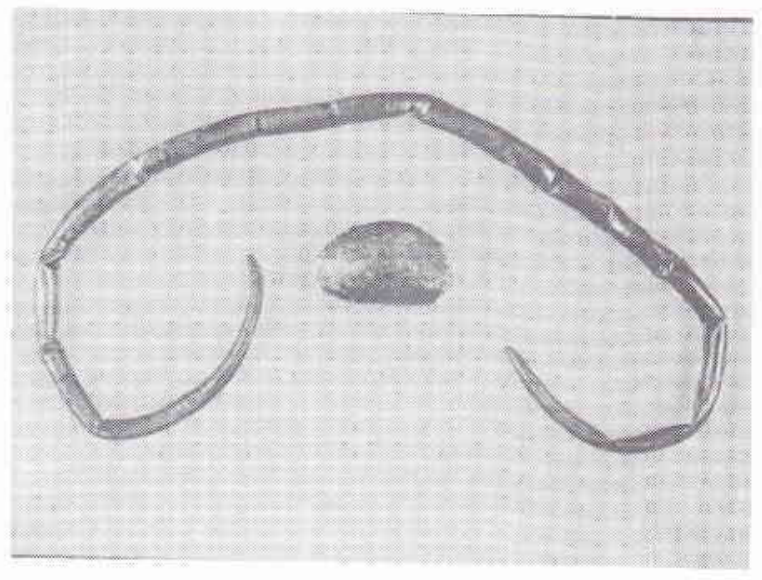

Figure 7. A worm and a common bile duct stone taken from the biliary tract at surgery 
clearance after oral anthelminthic treatment although this can be done with US by experienced sonologist.

Despite successful clearance of the biliary system, anthelminthic therapy is indicated for the treatment of the gut infestation and to prevent another worm from migrating up to the biliary-tract.

In endemic area, some have recommended 2 month antihelmintic therapy to avoid recurrent of the disease. $^{2}$

The remaining four patients with concurrent common bile duct stones underwent uneventful surgery. With the current availability of accesories for endoscopic treatment such as mechanical or electro-hydraulic lithotrypter, surgery might not be longer necessary in almost all hepatobiliary ascariasis cases associated with relative big $\mathrm{CBD}$ stones.

In conclusion, US and ERCP are very useful in the diagnosis of biliary ascariasis and endoscopic treatment should be considered as the first treatment of choice for those patients with symptomatic biliary obstruction and acute cholangitis.

\section{REFERENCES}

1. Louw JH. Abdominal complications of Ascaris lubricoides infestation in childhood. Br J. Surg 1966; 53: 510-21.
2. Khuroo MS, Zargar SA. Biliary ascariasis: a common cause of biliary and pancreatic disease in an endemic area. Gastroenterology 1985; 88: 418-23.

3. Yang SCH, Laube PJ. Biliary ascariasis-report of 19 cases. Am Surg 1946; 123: 299-303.

4. Wright RM, Dorrough RL, Ditmore HB. Ascariasis of the biliary system. Arch Surg 1963; 86: 402-5.

5. Khuroo MS, Zargar SA, Mahajou R, Bhat RL, Javid G. Sonographic appearances in biliary ascariasis. Gastroenterology 1987; 93: 267-72.

6. Leung JW, Chung SCS. Endoscopic management of biliary ascariasis. Gastrointestinal Endoscopy 1988; 34: 318-20.

7. Aslam M, Dore SP, Verbank JJ, De Soete CJ, Ghillebert GG. Ultrasonographic Diagnosis of Hepatobiliary Ascariasis. J Ultrasound Med. 1993; 12: 573-6.

8. Khuroo MS, Mahajan R, Zargar SA, Javid G, Japru S. Prevalence of biliary tract disease in India: a sonographic study in adult population in Kashmir. Gut 1989; 30: 201-5.

9. Ali M, Khan AN. Sonography of Hepatobiliary Ascariasis. J Clin Ultrasound 1996; 24: 235-41.

10. Kamath PS, Joseph DC, Chandron R, Rao SR, Sri Prakash ML, D'Cruz AJ. Biliary ascariasis: ultrasonography, endoscopic retrograde cholangiography, and biliary drainage. Gastroenterology 1986; 91: 730-2.

11. Chen YS, Den BX, Huong BL, Xu LZ. Endoscopic diagnosis and management of ascaris induced acute pancreatitis. Endoscopy 1986; 18: 127-8.

12. Moniliawi MS, Khattar WY, Helmy MM, Bucharth F. Endoscopic diagnosis and extraction of biliary ascariasis. Endoscopy 1986; 18: 204-5.

13. Van Severen M. Lengele B, Durevil J, Shapiro M, Dove Ch. Hepatic ascariasis. Endoscopy 1987; 19: 140-2.

14. Zarfar JA, Khuroo MS. Treatment of biliary ascariasis and its rationale. Gastroenterology 1987; 93: 668. 